\title{
Development of Learning Materials in E-Learning Courses with the Principles of Cognitive Theory of Multimedia Learning (CTML)
}

\author{
I Gde Wawan Sudatha $^{1 *}$, Ketut Pudjawan ${ }^{1}$, Alexander H. Simamora ${ }^{1}$ \\ ${ }^{1}$ Universitas Pendidikan Ganesha, Indonesia \\ *Corresponding author.Email: igdewawans@undiksha.ac.id
}

\begin{abstract}
The objectives to be achieved in this development are as follows: 1) describe the process of developing learning materials in the E-Learning Development course in accordance with the principles of cognitive theory of multimedia learning, 2) describe the feasibility of learning materials for the E-Learning Development course according to experts content and learning media experts. This research is focused on developing learning materials in the E-Learning Development course in accordance with the principles of cognitive theory of multimedia learning. The research subjects were one subject content expert, one learning design expert, one media expert, and 30 students for the trial. The data collection methods in this study were questionnaires and tests. The data analysis technique used in this research is qualitative descriptive analysis and quantitative descriptive analysis. The results showed that: 1) the process of developing learning materials through: a) the analysis stage, b) the design stage, c) the development stage, d) the implementation stage, and e) the evaluation stage, 2) the learning materials developed were feasible based on a review by: a) content experts with very good qualifications $(96.4 \%)$, b) learning design with very good qualifications (95\%), c) media experts with very good qualifications (96.5\%), and d) trials to students with very good qualifications (95.6\%). Based on the results of the development and feasibility that has been done, the learning materials are suitable for use in learning in the E-Learning course.
\end{abstract}

Keywords: Development, e-Learning, Instruction

\section{INTRODUCTION}

Technological innovation has led to changes in the teaching and learning process. Advances in computer technology allow the development of various multimedia learning environments. Multimedia allows combinations such as images, text, and sound via different channel modalities [1]. Variations of media such as text, graphics, audio, and video to convey interesting learning content for learners and learners to use in learning. The strategy for using media is an important part of learning. Multimedia presents material using words and pictures [2]. The use of the words in question is to present learning materials in verbal form such as printed text or voice text. The use of images in question is the presentation of learning materials in the form of pictorials, such as static graphics, where static graphics include illustrations, graphics, photos or maps, while dynamic graphics include animation or video. Multimedia can provide experience through the presentation of information in the form of text, graphics, images, audio, and video as well as combining images and words [3]. Therefore, multimedia learning is learning from words and pictures [2].

Multimedia has grown and developed very rapidly along with advances in computer-based communication and information technology. The shift in the educational paradigm due to the inclusion of constructivism has changed the teaching era to the learning era [4]. The advancement of multimedia technology is an opportunity to create interactive learning materials that support learning. Advances in technology make it easy to design learning media to bring real phenomena, in the form of videos of facts and daily life into the classroom [2]. The impact of technology is enormous in the transformation of education and how one teaches and learns. With computer technology, text and graphics can be transformed, manipulate colour and sound and use other computer influences to create dynamics and animation to 
present information [5]. Multimedia learning occurs when learners construct mental representations of the words and images presented (eg printed text and illustrations or narration and animation). The promise of multimedia learning is that learners can learn better from well-designed multimedia consisting of words and images than traditional learning models that are only words [2]. Multimedia has several important roles in learning [6], namely: 1) providing concrete idea references, 2) motivating students by increasing attention, maintaining attention, and generating emotional responses, 3) simplifying difficult information understood, 4) help organize the material by illustrating the relationship between elements in the form of a diagram, and 5) providing multiple channels or multimodality of information so as to facilitate understanding. Multimedia, especially computer-based ones, is widely used in learning that emphasizes learners' understanding [7]. Based on the explanation above, it is necessary to develop learning materials in the E-Learning Development course in accordance with the principles of cognitive theory of multimedia learning (CTML).

\section{METHODOLOGY OF RESEARCH}

This research is a development research. Development research is research oriented to develop and validate products used in education. Development research is not to create theories or test theories but to develop effective products for use in schools. The model used in this development research is the ADDIE model [8]. The ADDIE model includes analysis, design, development, implementation, and evaluation.

The ADDIE model is a system-oriented model, namely a learning design model to produce a learning system that has a broad scope, such as a training system design, school curriculum, and so on. The stages of this model are: a) analysis, the analysis stage is a process of defining what learners will learn, namely identifying problems, needs assessment (needs analysis), and conducting environmental analysis. Therefore, the media that will be produced are media based on the characteristics or profiles of prospective learners, identification of gaps, identification of needs and detailed task analysis based on needs, b) design, the design stage includes compiling the program structure, making storyboards, designing advance, systematic preparation of material presentation, illustration, visualization, c) development, the process of making a blueprint or design a reality. That is, if the design requires a software in the form of multimedia learning, then the multimedia must be developed. Or a print module is needed, then the module needs to be developed, d) implementation, concrete steps to implement the learning system we are creating. That is, at this stage everything that has been developed is installed or set in such a way as to its role or function so that it can be implemented, e) evaluation, the process of seeing whether the learning system being built is successful, according to initial expectations or not. The evaluation stage can occur at any of the four stages above. Evaluation that occurs in each of the four stages above is called formative evaluation, because its purpose is for revision needs.

Product development trials are an important part of development research. At this stage, the product being developed is evaluated through several stages so that the product is truly valid for use in learning activities. The stages of product validation include: (a) review by material experts, (b) review by instructional media experts, (c) individual trials, (d) small-group trials, and (e) field trials.

The data obtained through the trial activities were classified into two, namely qualitative data and quantitative data. Qualitative data in the form of criticism and suggestions put forward by instructional media experts and material experts are collected to improve the products being developed. Quantitative data regarding the quality of the product developed were obtained from material experts and instructional media experts through a questionnaire with a Likert scale analysed by descriptive statistics.

\section{RESULT AND DISCUSSION}

\subsection{Result}

In this study, a product in the form of teaching materials as content in E-learning is used in the ELearning course in the Educational Technology Department, FIP, Undiksha. This development is carried out in the development of teaching content in the form of instructional videos. This research was conducted on 25 semester students of the Educational Technology Department, FIP, Undiksha who programmed the ELearning course. The model used in the development of blended learning is the ADDIE model which consists of five stages, namely analysis, design, development, implementation, and evaluation. The results obtained in each stage are as follows. Stage analysis, this stage describes the results of the analysis activities that have been carried out, namely analysis of courses, analysis of student characteristics, and analysis of the environment, as well as the facilities already owned. Stage design, at the design stage, several activities were carried out, namely: 1) making a storyboard and 2) designing a draft of teaching materials. Stage development, the development stage is the stage of producing E-learning content as teaching materials that support learning. Stage implementation, several stages of product implementation are as follows. 1) Test product validation by experts, namely subject content experts, learning design experts, and learning media experts and 2) Product trials included individual trials consisting of three students, small group trials consisting of twelve students, 
and field trials covering all students programming ELearning courses. The purpose of this product trial is to determine the feasibility and quality of the teaching materials being developed. Stage evaluation, the evaluation stage is the final stage of evaluating the data that has been collected during the implementation stage. Evaluation is in the form of formative evaluation. Formative evaluation aims to assess products that have been developed covering expert validation, individual trials, small group trials, and field trials.

Based on the results of reviews conducted by experts and trials with students, the following results were obtained: a) content experts with very good qualifications $(96.4 \%)$, b) learning designs with very good qualifications $(95 \%)$, c) experts media with very good qualifications $(96.5 \%)$, and d) testing for students with very good qualifications $(95.6 \%)$.

\subsection{Discussion}

The development of teaching materials in the ELearning course uses the ADDIE development model. This development is designed to follow the ADDIE model stages consisting of five stages, namely: 1) the analysis stage (conducting a needs analysis), 2) the design stage, 3) the development stage, 4) the implementation stage, and 5) the evaluation stage.

The first step is an analysis which includes (1) subject analysis is carried out to determine the characteristics of the field of study, indicators, and learning objectives. At this stage, material selection is also carried out to determine the increase in learning outcomes after and before learning is carried out. Analysis of the environment, facilities and availability of learning resources. Based on the researcher's experience, it was found that campus facilities such as computer laboratories, internet networks were adequate.

The second step is design. At this stage the activities carried out, namely 1) preparing the design of teaching materials and 2) creating a storyboard for E-learning teaching materials, namely in the form of learning videos and tutorials. The third step is development (development). At this stage the activities carried out are developing learning video teaching materials.

The fourth step is implementation. At this stage, implementation activities from the teaching materials that have been developed are carried out. Prior to implementation, a product validation test was carried out by subject experts, learning design experts, and instructional media experts. After going through the product validation test from the experts then continued with individual testing, small group testing, and field testing.

The fifth step is evaluation. At this stage, perform a formative evaluation. Formative evaluation aims to assess products that have been developed covering expert validation, individual trials, small group trials, and field trials.

\section{CONCLUSSION}

Based on the results of research and discussion, the following conclusions are obtained. 1) The process of developing learning materials is through: a) the analysis stage, b) the design stage, c) the development stage, d) the implementation stage, and e) the evaluation stage, 2) The learning materials developed are feasible based on reviews by: a) subject content experts with very good qualifications $(96.4 \%)$, b) learning designs with very good qualifications $(95 \%)$, c) media experts with very good qualifications $(96,5 \%)$, and d) testing for students with very good qualifications $(95.6 \%)$.

\section{AUTHORS' CONTRIBUTIONS}

The author of this article contributes to the development of learning media, learning media evaluation instruments, learning media trials, and article writing.

\section{ACKNOWLEDGMENTS}

The author would like to thank all the support from the Universitas Pendidikan Ganesha so that the resulting research processes and products can be used in learning.

\section{REFERENCES}

[1] H. Horz, W. Schnotz, Cognitive Load in Learning with Multiple Representations, in: Plaas, J., L., Moreno, R., Brunken, R., (Ed.), Cognitive Load Theory, New York: Cambridge University Press, 2010.

[2] R. E. Mayer, Multimedia learning, New York: Cambridge University Press, 2009.

[3] A. P. Gilakjani, A Study on the Impact of Using Multimedia to Improve the Quality of English Languange Teaching, Journal of Languange Teaching and Research 3(6) (2012) 1208-1215.

[4] C. M. Reigeluth, Instructional Design Theory and Models, Vol 2, London: Lawrence Erlbaum Associates, 1999.

[5] H. Kassim, The relationship between learning style, creative thinking performance and multimedia learning materials, Journal Procedia Social and Behavioral Science, 97, 2013, 229-237.

[6] S. E. Smaldino, J. D. Russel, R. Heinich, R., and M. Molenda, Instructional Technology and Media for Learning (8th Ed.), Upper Saddle River: Pearson Education Inc, 2005.

[7] M. D. Roblyer, A. H. Doering, Integrating educational technology into teaching, (5th ed.), Upper Saddle River: Pearson, 2010.

[8] R. M. Branch, Instructional Design: The ADDIE Approach, New York: Springer, 2009. 